\title{
Statyba
}

\section{FREE VIBRATION ANALYSIS OF REISSNER-MINDLIN PLATES BY A MODIFIED LINKED INTERPOLATION ELEMENT}

\section{R. Baušys}

To cite this article: R. Baušys (1999) FREE VIBRATION ANALYSIS OF REISSNER-MINDLIN PLATES BY A MODIFIED LINKED INTERPOLATION ELEMENT, Statyba, 5:2, 83-90, DOI: 10.1080/13921525.1999.10531441

To link to this article: https://doi.org/10.1080/13921525.1999.10531441

曲 Published online: 26 Jul 2012.

Submit your article to this journal $₫$

Џll Article views: 144 


\section{FREE VIBRATION ANALYSIS OF REISSNER-MINDLIN PLATES BY A MODIFIED LINKED INTERPOLATION ELEMENT}

\section{R. Baušys}

\section{Introduction}

During the last decade a considerable amount of the research has gone into implementation of Reissner-Mindlin theory $[1,2]$ to plate problems, especially in the field of the finite elements. The classical Poisson-Kirchoff theory of plates requires $C^{l}$-continuity. In order to construct multidimensional $C^{l}$ interpolations must be taken of considerable ingenuity and the resulting schemes have always been extremely complicated in one way or another. Plate elements derived from Reissner-Mindlin theory possess several appealing advantages. First, the inclusion of shear deformation and rotary inertia has considerable effect on the higher modes of thin plates and even on lower modes of thick plates. Secondly, the construction of the finite element formulation based on this approach requires only $C^{0}$-continuity of the solution. Such continuity is easily achieved, and permits a great deal of flexibility in the specification of approximation functions over an element. The Reissner-Mindlin theory is applicable to thin as well as moderately thick plates that covers the most engineering applications.

In the earliest use of Reissner-Mindlin plate elements, independent interpolation of transverse displacements of the mid-plane $(w)$ and of the rotations $\underline{\theta}=\left(\theta_{x}, \theta_{y}\right)^{T}$ was assumed in a "displacement" type formulation allowing for transverse shear deformations. Although this bypasses the difficulties caused by $C^{1}$ requirements of the classical Kirchoff theory, its direct applications to thin plate situations induce often "shear locking" behaviour. Due to this, enormous attempts for deriving robust elements for ReissnerMindlin plate bending problems have been made. For instance, the use of reduced or selectively reduced integration, of assumed transverse strain fields and of directly introducing independent variables for transverse shear resultants $S=\left(S_{x}, S_{y}\right)^{T}[3,4]$. In general, additional fields may be discontinuous from element to element so that the corresponding unknowns can be eliminated on the element level which enables to reduce order element stiffness matrix.

A finite element formulation is of a mixed type if, according to [5], governing equations which are of reducible type are used to derive weak forms, in which continuous functions are approximated with piecewise polynomials. The most widely used one is the case when the transverse displacement, rotations and the transverse shear resultants are independently interpolated; yielding a three field mixed problem. Recent studies have shown that the performance of such mixed formulation can significantly be improved if a linked interpolation is used for the transverse displacements, eg

$$
w=\mathbf{N}_{\mathrm{w}} \bar{w}+\mathbf{N}_{w \theta} \underline{\bar{\theta}} \quad, \underline{\theta}=\mathbf{N}_{\theta} \underline{\bar{\theta}} \text { and } \mathbf{S}=N_{S} \bar{S},
$$

where $\overline{\boldsymbol{w}}, \underline{\bar{\theta}}$ and $\bar{S}$ are appropriate parameters of transverse displacements, rotations and shear resultants and, $N_{w}, N_{w \theta}, N_{\theta}$ and $N_{S}$ are corresponding interpolation functions. Generally, the functions $N_{S}$ are discontinuous over element boundaries and, thus, the parameters $\bar{S}$ can be eliminated at element level resulting in a simple displacement form of the final equations.

In [6], the mixed formulation with linked interpolation to linear elastodynamic problems have been applied and reported numerical tests on the four node quadrilateral element, Q4BL, for free vibration analysis. Numerical experiments given in [6] have shown good performance of the element Q4BL. However, it has been found that this element has zero-energy mode for patch tests with relaxed boundary conditions. An alternative quadrilateral element for Reissner-Mindlin plates, which extends the mixed formulation using linked interpolation and has no zero-energy mode, was developed for static problems in [7]. In this paper, we have extended this formulation to dynamic problems and perform a parametric study of this ele- 
ment for free vibration problems. Several numerical examples are given to study the performance of the element Q4BLa when implemented to free vibration problems. Validity of the present numerical experiments is demonstrated by comparing the finite element solutions with the results obtained using closed form 3-D solutions, closed form Reissner-Mindlin plate solutions and solutions based on thin plate theory and the results obtained using widely used 3-D finite elements.

\section{Mixed finite element formulation with linked inter- polation for linear elastodynamics}

The basic assumptions used in the ReissnerMindlin plate theory are as follows:

(1) Plane sections normal to the mid-plane remain plane after deformations;

(2) Stress normal to the mid-plane is negligible, ie $\sigma_{\mathrm{zz}}=0$.

Upon these assumptions, the governing equations for both thick and thin plates can, with regard to inertia effects, be written as [8]

$$
\begin{gathered}
-\frac{\rho t^{3}}{12} \ddot{\theta}+L^{T} D L \underline{\theta}+S=0 \\
\frac{S}{\beta G t}+\underline{\theta}-\nabla w=0 \\
-\rho t \ddot{w}+\nabla^{T} S+q=0
\end{gathered}
$$

when there are no viscous-damping forces. This equation system can serve as the foundation on which a mixed discretization is built. In above, the dots denote the derivative with respect to time, $L$ is the strain operator and $\nabla$ is the gradient operator defined as

$$
\boldsymbol{L}=\left[\begin{array}{cc}
\partial / \partial x & 0 \\
0 & \partial / \partial y \\
\partial / \partial y & \partial / \partial x
\end{array}\right], \quad \nabla=\left(\begin{array}{l}
\partial / \partial x \\
\partial / \partial y
\end{array}\right)
$$

and $D$ is the bending rigidity, eg for isotropic materials

$$
D=\frac{E t^{3}}{12\left(1-v^{2}\right)}\left[\begin{array}{llc}
1 & v & 0 \\
v & 1 & 0 \\
0 & 0 & (1-v) / 2
\end{array}\right]
$$

Here, $E$ is the Young's modulus, $t$ - the thickness, $v$ - the Poisson's ratio, $\rho$ is the mass density, $G$ - the shear modulus and $\beta$ - a parameter to account for non-uniform distribution of the transverse shear stress across the section, respectively. The governing equa- tions for thin plate limits are special cases of (1) with $G \rightarrow \infty$.

Using standard Galerkin procedure we weigh the partial differential equation (1a) by $\vartheta_{\theta}=N_{\theta} \bar{a},(1 \mathrm{~b})$ by $\underline{\vartheta_{S}}=N_{s} \bar{b}$ and (1c) by $\underline{\vartheta}_{w}=N_{w} \bar{c}+N_{w \theta} \bar{d}$, we obtain after integration by parts the semidiscrete, symmetric system of equations in the following form (see Zienkiewicz \& Taylor [5] for detailed derivation in static cases):

$$
\left[\begin{array}{ccc}
\boldsymbol{M}_{\theta \theta} & 0 & \boldsymbol{M}_{\theta w} \\
0 & 0 & 0 \\
\boldsymbol{M}_{\theta w}^{T} & 0 & \boldsymbol{M}_{w w}
\end{array}\right]\left(\begin{array}{l}
\ddot{\theta} \\
\ddot{\boldsymbol{S}} \\
\ddot{\boldsymbol{w}}
\end{array}\right)+\left[\begin{array}{ccc}
\boldsymbol{A} & \boldsymbol{B} & 0 \\
\boldsymbol{B}^{T} & \boldsymbol{P} & \boldsymbol{C} \\
0 & \boldsymbol{C}^{T} & 0
\end{array}\right]\left(\begin{array}{l}
\underline{\theta} \\
\boldsymbol{S} \\
w
\end{array}\right)=\left(\begin{array}{c}
f_{\theta} \\
0 \\
\boldsymbol{f}_{w}
\end{array}\right)
$$

where the submatrices in the "stiffness" matrix are

$$
\begin{aligned}
A & =\int_{\Omega}\left(L N_{\theta}\right)^{T} D\left(L N_{\theta}\right) d \Omega \\
B & =\int_{\Omega} N_{\theta}^{T} N_{S} d \Omega+\int_{\Omega}\left(\nabla N_{w \theta}\right)^{T} N_{S} d \Omega \\
C & =\int_{\Omega} N_{S}^{T} \nabla N_{w} d \Omega \\
P & =\int_{\Omega} N_{S}^{T} \frac{1}{\beta G t} N_{S} d \Omega
\end{aligned}
$$

and those in the "mass" matrix

$$
\begin{aligned}
M_{\theta \theta} & =\int_{\Omega} N_{w \theta}^{T} \rho t N_{w \theta} d \Omega+\int_{\Omega} N_{\theta}^{T} \frac{\rho t}{12} N_{\theta} d \Omega \\
M_{\theta \theta} & =\int_{\Omega} N_{w \theta}^{T} \rho t N_{w} d \Omega \\
M_{w w} & =\int_{\Omega} N_{w}^{T} \rho t N_{w} d \Omega
\end{aligned}
$$

and the force terms

$$
\bar{f}_{\theta}=\int_{\Omega} N_{w \theta}^{T} q d \Omega, \bar{f}_{w}=\int_{\Omega} N_{w}^{T} q d \Omega
$$

if the boundary tractions are assumed to be zero. The second term on the right hand side of (5) corresponds to the rotary inertia effects, which are of considerable importance in thick plate situation [5].

The equation (3) are three-field mixed problem. Since shear forces are assumed to be discontinuous over element interfaces, it is possible alternatively to eliminate the parameters $\overline{\mathbf{S}}$ (at element level) yielding a system of equations in the displacement form 


$$
\left[\begin{array}{ll}
\boldsymbol{M}_{\theta \theta} & \boldsymbol{M}_{\theta w} \\
\boldsymbol{M}_{\theta w}^{T} & \boldsymbol{M}_{w w}
\end{array}\right]\left(\begin{array}{l}
\ddot{\theta} \\
\ddot{\boldsymbol{w}}
\end{array}\right)+\left[\begin{array}{ll}
\boldsymbol{K}_{\theta \theta} & \boldsymbol{K}_{\theta w} \\
\boldsymbol{K}_{\theta w}^{T} & \boldsymbol{K}_{w w}
\end{array}\right]\left(\begin{array}{l}
\underline{\theta} \\
\boldsymbol{w}
\end{array}\right)=\left(\overline{\overline{f_{\theta}}}\right)
$$

where

$$
\begin{gathered}
\boldsymbol{K}_{\theta \theta}=\boldsymbol{A}-\boldsymbol{B} \boldsymbol{P}^{-1} \boldsymbol{B}^{T} \\
\boldsymbol{K}_{\theta w}=-\boldsymbol{B} \boldsymbol{P}^{-1} \boldsymbol{C} \\
\boldsymbol{K}_{w w}=-\boldsymbol{C}^{T} \boldsymbol{P}^{-1} \boldsymbol{C}
\end{gathered}
$$

In free vibration analysis, the governing equations will be of the form

$$
\left(\left[\begin{array}{ll}
\boldsymbol{K}_{\theta \theta} & \boldsymbol{K}_{\theta w} \\
\boldsymbol{K}_{\theta w}^{T} & \boldsymbol{K}_{w w}
\end{array}\right]-\omega^{2}\left[\begin{array}{ll}
\boldsymbol{M}_{\theta \theta} & \boldsymbol{M}_{\theta w} \\
\boldsymbol{M}_{\theta w}^{T} & \boldsymbol{M}_{w w}
\end{array}\right]\right)\left(\begin{array}{l}
\theta \\
\boldsymbol{w}
\end{array}\right)=\left(\begin{array}{l}
\boldsymbol{0} \\
\boldsymbol{0}
\end{array}\right)
$$

where $\omega$ is the eigenfrequency.

\section{Mixed quadrilateral element Q4BLa}

For clarity, a brief description of the element Q4BLa will be given in this section. Considered element has nodal parameters shown in Fig 1.

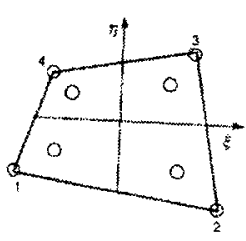

$\underline{\bar{\theta}}$ parameters

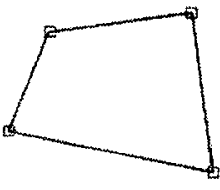

$\bar{w}$ parameters

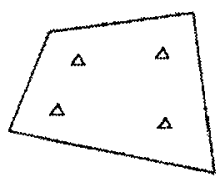

$\bar{S}$ parameters
Fig 1. Nodal parameters of the mixed element Q4Bla by Xu et al [7]

Appropriate shape functions and parameters as approximate the variables of the elements

$$
\begin{gathered}
w=\sum_{i=1}^{4} N_{w}^{i} \overline{w^{i}}+\sum_{k=1}^{4} N_{w \theta}^{k}\left(\theta_{k}^{2}-\theta_{k}^{l}\right) h_{k} \\
\underline{\theta}=\sum_{i=1}^{4} N_{\theta}^{i} \frac{\bar{\theta}^{i}}{+}+\sum_{j=1}^{4} N_{\theta}^{j} \Delta \bar{\theta}^{j} \\
S=\sum_{j=1}^{4} N_{S}^{j} \overline{S^{j}}
\end{gathered}
$$

where $i$ and $k$ denote the corner node number and side number, respectively, $j$ denotes the internal nodes. Here, both $N_{w}^{i}$ and $N_{\theta}^{i}$ are bilinear shape functions, $N_{\theta}^{j}$ are functions associated with each vertex of the element

$$
\begin{array}{r}
N_{\theta}^{i+4}=\left(1-\xi^{2}\right)\left(1-\eta^{2}\right)\left(1+\xi_{i} \xi\right)\left(1+\eta_{i} \eta\right), \\
i=1,2,3,4 .
\end{array}
$$

$N_{s}$ are linear shape functions for shear force interpolation. In this case, a discontinuous interpolation over element interfaces for shear forces is still assumed. $N_{w \theta}^{k}(\mathrm{k}=1,2,3,4)$ is a linear-quadratic linking shape function associated with side $\mathrm{k}$ whose length is $h_{k}$ and $\theta_{k}^{l}$ is the rotations in the tangential direction of side $k$ at its two ends, respectively ( see Fig 2 for side 1-2). For more details, we refer to [6].

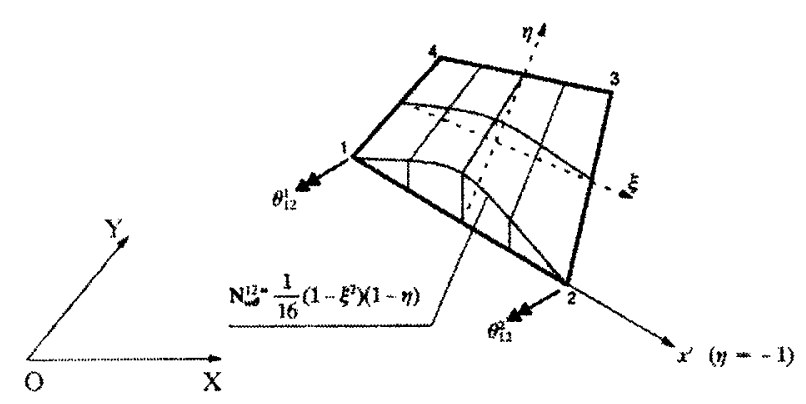

Fig 2. Linking shape function $N_{w \theta}$ for side 1-2

As discussed in [9], one of the most important criteria of stability for any element assembiy and boundary conditions is that

$$
n_{\theta}+n_{w} \geq n_{s}, \quad n_{s} \geq n_{w}
$$

where $n_{\theta}, n_{w}$ and $n_{S}$ are the number of parameters defining the approximations of $\underline{\bar{\theta}}, \bar{w}$ and $\bar{S}$. If this necessary condition is not satisfied, the equation system (6) would be singular. This condition must be satisfied not only for the whole system but it needs to be satisfied for separate element patches to avoid local instabilities.

For static analysis, the parameters of the internal rotations and shear resultants can easily be eliminated at the element level, yielding a four node quadratic element with 12 degrees of freedom. Numerical examples given in [7] indicate that this element is efficient and robust under most practical situations for linear elastostatics. When applying the element to dynamic problems, we eliminate in this study only the shear resultants and, thus, keep 20 degrees of freedom as was successfully done for the free vibration analysis in [6].

Notice that the submatrix $M_{\theta \theta}$ is evaluated through the integration of a sixth order polynomial, 
$\boldsymbol{M}_{\theta w}$ of a fourth order polynomial and $\boldsymbol{M}_{w w}$ of a second order polynomial. Hence, different integration rules can be used for different submatrices to improve computational efficiency. If the nodal quadrature [4] is used, a "lumped" mass matrix of the following form

$$
\boldsymbol{M}=\left[\begin{array}{cc}
\frac{\rho t^{3}}{12} \boldsymbol{I} & 0 \\
0 & \rho t I
\end{array}\right]
$$

where $I$ is an identity matrix, is obtained with rotary inertia term on the up-left corner.

\section{Numerical examples}

Two different types of polygonal plates were chosen to provide example numerical results. Both cases of thin and thick plates are discussed. Three different types of boundary conditions are considered:

- Simply supported edge (S),

- Clamped edge (C),

- Free edge $(\mathrm{F})$.

A simple convention is adopted to define the boundary conditions in a particular case. For example, S-CS-F implies two opposite edges are simply supported with clamped and free boundary conditions on other edges.

In the following, we shall denote finite element meshes by $\left(n_{1} \times n_{2}\right)$, where $n_{1}$ and $n_{2}$ represents the number of elements in $\mathrm{X}$ and $\mathrm{Y}$ direction, respectively. We shall also denote different eigenmodes by $\left(m_{1}, m_{2}\right)$ to indicate a mode with $m_{1}$ and $m_{2}$ half waves in $\mathrm{X}$ and $\mathrm{Y}$ direction, respectively.

The case of consistent mass formulation is considered for all numerical experiments.

\section{1. Square plates}

A square plate with symmetric boundary conditions $\mathrm{S}-\mathrm{S}-\mathrm{S}-\mathrm{S}$ is considered as the first example. We shall use uniform meshes for our finite element analysis. Eigenfrequencies are presented in nondimensionalized form, $\omega t \sqrt{\rho / G}$.

In Table 1, non-dimensionalized eigenfrequencies for a number of the low modes are given for plates with thickness ranging from $t / L=0.001$ to $t / L=0.5$. For the sake of comparison, some numerical results obtained in [10] using a 6 node triangular mixed element with linked interpolation are given in the table. In addition, closed form solutions for thin plates [11] and for thick plates [12] and using 3D elasticity theory [13] are also included. It can been seen from presented results there is in all thickness-to-span $(t / L)$ cases good agreement between the thick plate theory solutions based on the closed form and present finite element formulation.

For the sake of illustration, the convergence studies for square plates with different boundary conditions are presented. In Figs 3-6, convergence for element Q4BLa of the first and sixth eigenfrequencies are presented. For both cases thickness-to-span ratio has been chosen to be 0.1 .

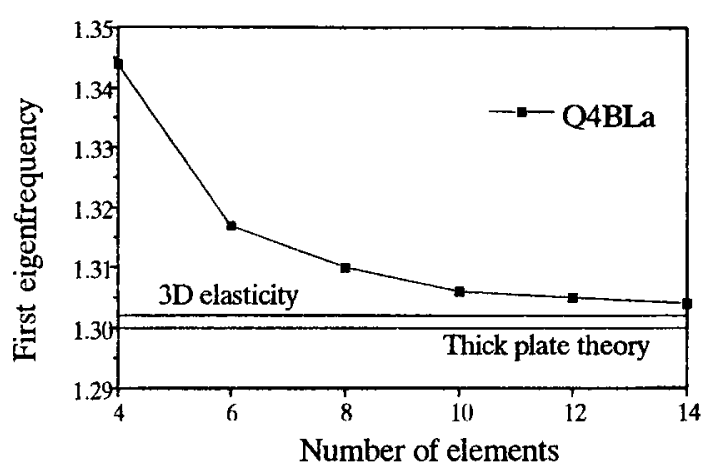

Fig 3. Convergence study on first eigenfrequency of S-C-S-C square plate

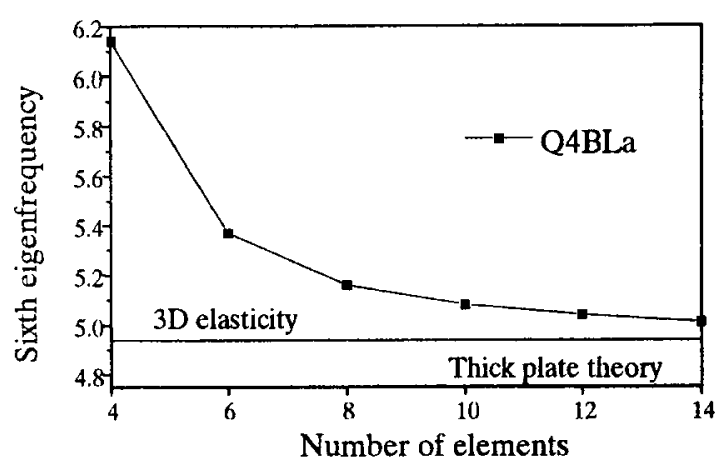

Fig 4. Convergence study on sixth eigenfrequency of S-C-S-C square plate

We observe fast convergence to the closed form solutions based on thick plate and 3-D elasticity theories. Boundary conditions have no influence on the performance of the element Q4Bla. 
Table 1. Non-dimensionalized eigenfrequencies $\omega t \sqrt{\rho / G}$ for a simply supported (SS2) square plate

\begin{tabular}{|c|c|c|c|c|c|c|}
\hline$t / L$ & mode & Q4BLa & $\begin{array}{c}\text { Papadopolos \& } \\
\text { Taylor [10] }\end{array}$ & $\begin{array}{c}\text { Thick plate theory } \\
{[12]}\end{array}$ & 3 elasticity [13] & $\begin{array}{c}\text { Thin plate theory } \\
{[11]}\end{array}$ \\
\hline 0.01 & $(1,1)$ & $0.9631 \mathrm{E}-3$ & $0.9628 \mathrm{E}-3$ & - & - & $0.9632 \mathrm{E}-3$ \\
0.01 & $(1,2)$ & $0.2412 \mathrm{E}-2$ & - & - & - & $0.2408 \mathrm{E}-2$ \\
0.01 & $(2,2)$ & $0.3853 \mathrm{E}-2$ & - & - & - & $0.3853 \mathrm{E}-2$ \\
0.01 & $(1,3)$ & $0.4846 \mathrm{E}-2$ & $0.4831 \mathrm{E}-2$ & - & - & $0.4816 \mathrm{E}-2$ \\
0.01 & $(2,3)$ & $0.6276 \mathrm{E}-2$ & - & - & - & $0.6261 \mathrm{E}-2$ \\
0.01 & $(1,4)$ & $0.8299 \mathrm{E}-2$ & - & - & - & $0.8187 \mathrm{E}-2$ \\
0.01 & $(3,3)$ & $0.8680 \mathrm{E}-2$ & $0.8616 \mathrm{E}-2$ & - & - & $0.8668 \mathrm{E}-2$ \\
\hline 0.1 & $(1,1)$ & 0.09306 & - & 0.09300 & 0.09315 & 0.09632 \\
0.1 & $(1,2)$ & 0.22643 & - & 0.22176 & 0.22260 & 0.24079 \\
0.1 & $(2,2)$ & 0.34155 & - & 0.34018 & 0.34207 & 0.38527 \\
0.1 & $(1,3)$ & 0.41935 & - & 0.41440 & 0.41714 & 0.48159 \\
0.1 & $(2,3)$ & 0.52475 & - & 0.51974 & 0.52391 & 0.62606 \\
0.1 & $(3,3)$ & 0.69007 & - & 0.68208 & 0.68893 & 0.86686 \\
0.1 & $(2,4)$ & 0.75904 & - & 0.74312 & 0.75111 & 0.96317 \\
0.1 & $(1,5)$ & 0.95866 & - & 0.91520 & 0.92678 & 1.2521 \\
\hline 0.2 & $(1,1)$ & 0.34080 & - & 0.34018 & 0.34207 & 0.38527 \\
0.2 & $(1,2)$ & 0.74811 & - & 0.74312 & 0.75111 & 0.96317 \\
0.2 & $(2,2)$ & 1.0821 & - & 1.0735 & 1.0889 & 1.5411 \\
\hline 0.3 & $(1,1)$ & 0.68411 & - & 0.68208 & 0.68893 & 0.86686 \\
\hline 0.4 & $(1,1)$ & 1.0778 & - & 1.0735 & 1.0889 & 1.5411 \\
\hline 0.5 & $(1,1)$ & 1.4962 & - & 1.4890 & 1.5158 & 2.4079 \\
\hline
\end{tabular}

\subsection{Skew plates}

In order to study the performance of the element Q4BLa with distorted geometry we present the results clamped skew plate shown in Fig 7. As the skew angle $\alpha$ increases, element distortion becomes quite significant. The eigenfrequencies are reported in the of nondimensionalized parameter $\omega L^{2} \sqrt{\rho t / D}$, where $D=E t^{3} /\left[12\left(1-v^{2}\right)\right]$ is the plate flexural rigidity. The numerical results are compared with the results of closed form of 3-D solution and with the results of 3$D$ finite element analyses [14]. The results of 3-D finite element analysis are obtained by widely used MSC/NASTRAN CHEXA and COSMIC/NASTRAN CIHEX1 isoparametric brick elements. For the first case ratio $t / L$ is set to be 0.2 . It should be stated that three elements through thickness have been used for CHEXA elements and one element through thickness for CIHEX1 elements.

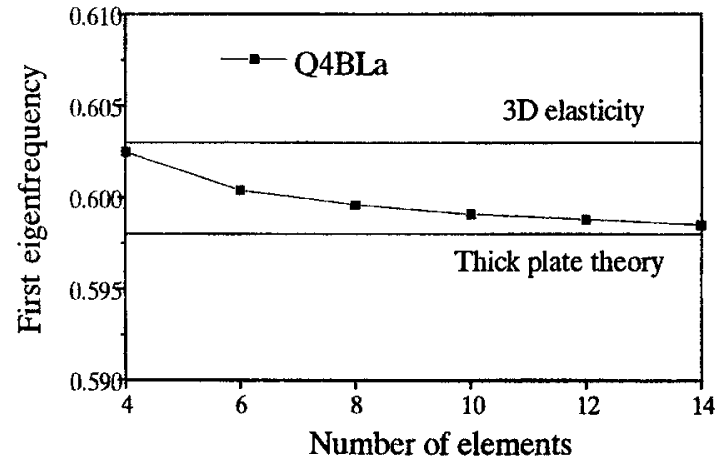

Fig 5. Convergence study on first eigenfrequency of S-C-S-F square plate

The results of numerical simulation are taken from (14x14) mesh size. The study how eigenfrequencies vary with the skew angle $\alpha$ increasing from $0^{\circ}$ to $45^{\circ}$ is presented in Figs 8-9. 


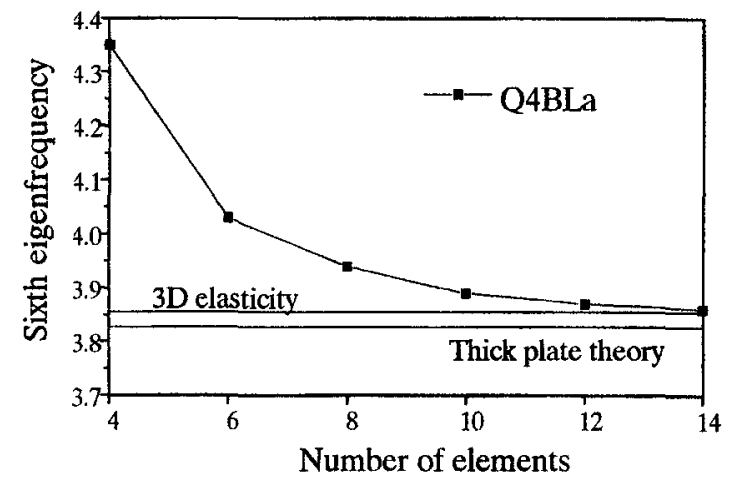

Fig 6. Convergence study on sixth eigenfrequency of S-C-SF square plate

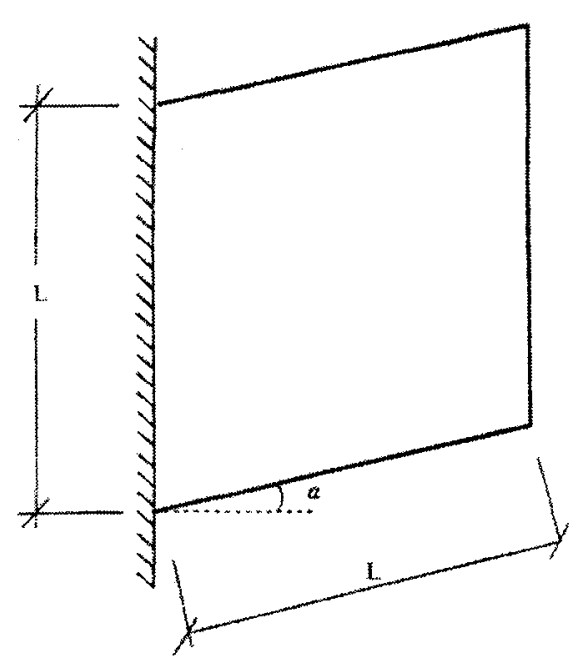

Fig 7. A skew cantilever thick plate

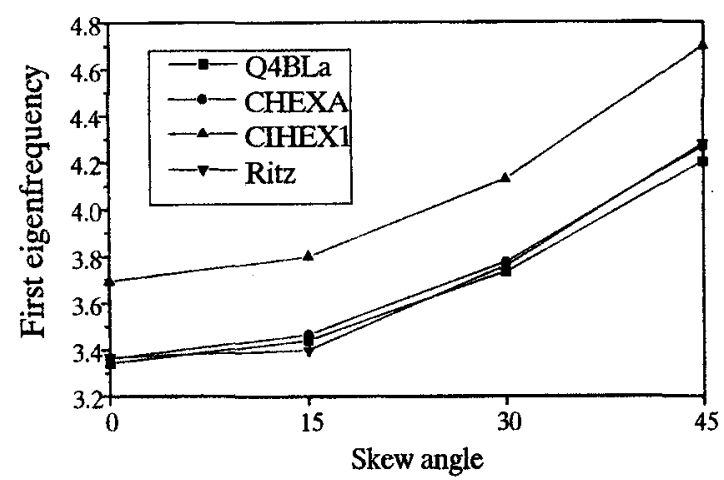

Fig 8. First eigenfrequency variation with skew angle increasing for plates $(t / L=0.2)$

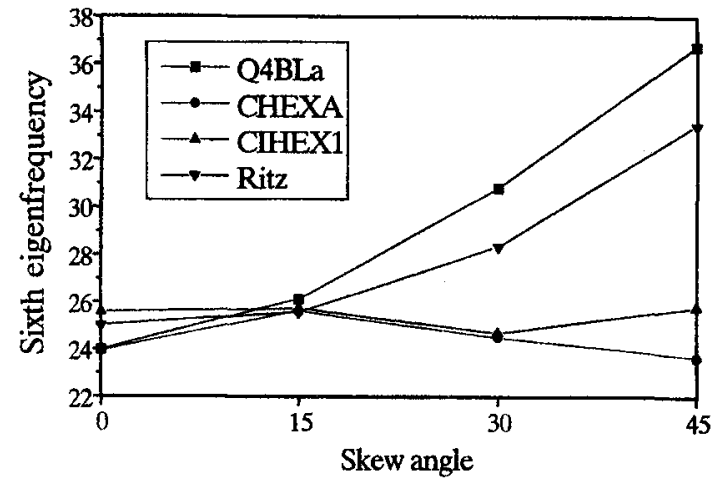

Fig 9. Sixth eigenfrequency variation with skew angle increasing for plates $(t / L=0.2)$

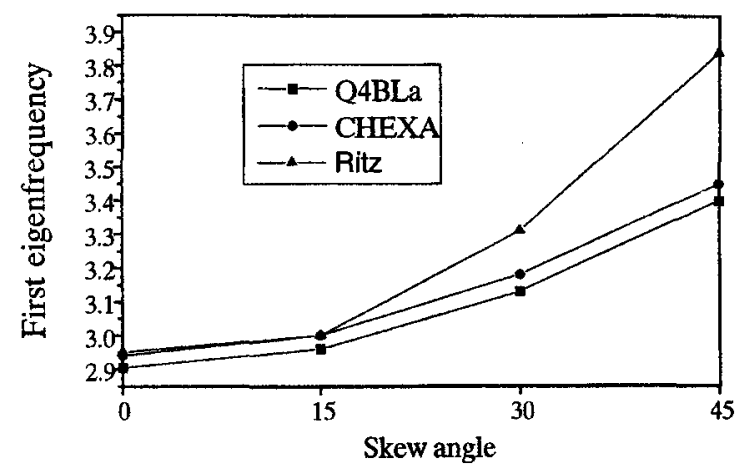

Fig 10. First eigenfrequency variation with skew angle increasing for plates $(t / L=0.5)$

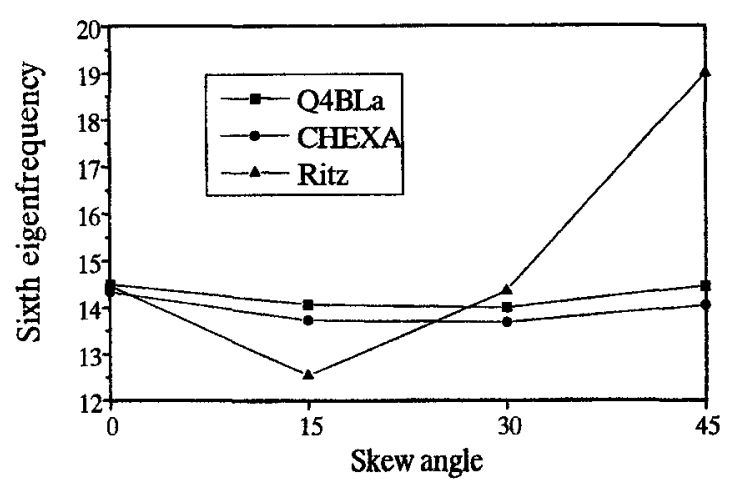

Fig 11. Sixth eigenfrequency variation with skew angle increasing for plates $(t / L=0.5)$ 
In the case of first eigenfrequency, results of the element Q4Bla show a good agreement with the results obtained by Ritz method and 3-D finite element analysis using the element CHEXA. For the sixth eigenfrequency, element Q4Bla has better performance compared with 3-D CIHEX1 finite element analysis.

In Figs 10-11 the influence of a skew angle $\alpha$ on the quality of the eigenfrequencies of skew plates with thickness-to-span ratio equal 0.5 has been studied. All numerical results are obtained using $(14 \times 14)$ mesh.

Comparatively speaking, element Q4Bla and 3-D finite element analysis results show analogous trends with increasing the skew angle, but they do not show a good numerical agreement with 3-D Ritz solution especially for the higher values of the skew angle.

\section{Conclusions}

This paper has presented the parametric study of the free vibrations of plates with various thickness-tospan ratios and different boundary conditions using Q4BLa element. As it can been seen from the presented numerical experiments, in all cases a good agreement between Reissner-Mindlin plate theory solutions based on the closed form and results obtained using Q4BLa element. The sensitivity to the distortion of the elements has been studied using the numerical simulation of the skew thick plates. The studied element shows a good performance in comparison with 3-D Ritz analysis of the plates with lower aspect ratio $(t / L=0.2)$.

\section{References}

1. E. Reissner. The effect of transverse shear deformation on the bending of elastic plates // J. Appl. Mech. Trans. ASME, 12, 1945, p. a69-a77.

2. R. D. Mindlin. Influence of rotary inertia and shear on flexural motions of isotropic elastic plates // J. Appl. Mech., 37, 1951, p. 1031-1036.

3. E. D. L. Pugh, E. Hinton and O. C. Zienkiewicz. A study of quadrilateral plate bending elements with reduced integration // Int. J. Numer. Meth. Engng., 12, 1978, p. 1059-1079.

4. D. S. Malkus and T. J. R. Hughes. Mixed finite element methods - reduced and selective integration techniques: unification of concepts // Comp. Meth. Appl. Mech. Eng., 15, 1978, p. 63-81.

5. O. C. Zienkiewicz and R. L. Taylor. The Finite Element Method (4th Ed), Vol. 2, McGraw-Hill, N. Y., 1992. 807 p.

6. N.-E. Wiberg, R. Baušys and L. F. Zeng. Free Vibration Analysis of Reissner-Mindlin Plates Using Linked Interpolated Mixed Formulation // Comput. and Struct., 52, 1994, p. 979-986.
7. Z. Xu, O. C. Zienkiewicz and L. F. Zeng. Linked interpolation for Reissner-Mindlin plate elements: Part III An Alternative Quadrilateral // Int. J. Numer. Meth. Engng., 37, 1994, p. 1437-1443.

8. K. Washizu. Variational Methods in Elasticity and Plasticity. Pergamon Press, 1968. 386 p.

9. O. C. Zienkiewicz, S. Qu, R. L. Taylor and S. Nakazawa. The pach test for mixed formulation // Int. J. Numer. Meth. Engng., 23, 1986, p. 1873-1883.

10. P. Papadopoulos and R. L. Taylor. A Triangular Element Based on Reissner-Mindlin Plate Theory // Int. J. Numer. Meth. Engng, 30, 1990, p. 1029-1049.

11. S. Timoshenko and S. Woinowsky-Krieger. Theory of plates and shells. McGraw-Hill, London, 1959. 389p.

12. D. J. Dawe and O. L. Roufaeil. Rayleigh-Ritz vibration analysis of Mindlin plates // J. Sound Vibr., 69, 1980, p. 345-359.

13. S. Srinivas, C. V. Joga Rao and A. K. Rao. An exact analysis for vibration of simply supported homogeneous and laminated thick rectangular plates // J. Sound Vibr., 12, 1970, p. 187-199.

14. O. G. McGee and A. W. Leissa. Three-dimensional free vibrations of thick skewed cantilevered plates $/ / \mathrm{J}$. Sound Vibr., 144, 1991, p. 305-322.

İteikta 19990118

\section{REISSNER-MINDLIN PLOKŠTELIU LAISVUUJU SVYRAVIMU ANALIZÉ TAIKANT MODIFIKUOTAZ MIŠRIOS FORMULUOTĖS ELEMENTĄ}

\section{R. Baušys}

\section{Santrauka}

Šiame darbe atlikta plokšteliu laisvuju svyravimų analizè, taikant mišrios formuluotès elementą Q4BLa. Taikant klasikinę Kirchoffo plokštelių teoriją, elementu interpoliacinès funkcijos turi atitikti $C^{l}$ tolydumo reikalavimus. Sudaryti tokias interpoliacines funkcijas nèra lengvas uždavinys, ypač sprendžiant daugiamates problemas. Antra vertus, gaunamos skaitinès shemos yra pakankamai sudètingos. Elementų, paremtų Reissner-Mindlin plokštelių teorija, interpoliacines funkcijos turi atitikti tiktai $C^{0}$ tolydumo reikalavimus. Tai labai palengvina elemento interpoliaciniu funkcijų sudarymą. Elementai, sukurti šios teorijos pagrindu, tinka tiek plonoms, tiek storoms plokštelèms modeliuoti. Pirmiesiems šios klasès elementams buvo taikytos savarankiškos interpoliacinès funkcijos illinkiu ir posūkiu lauku aproksimacijai. Tačiau, taikant šiuos elementus, pastebètas "šlyties užsikirtimo" fenomenas. Norint išvengti šio fenomeno, panaudotos savarankiškos interpoliacinès funkcijos šlyties jègų aproksimacijai. Pastarujų metụ tyrinèjimai parode, jog taikant interpoliacines funkcijas, susiejančias ịlinkiu ir posūkių laukus, galima pasiekti daug geresniu skaitinių rezultatų. Šis būdas leidžia taikyti aukštesnès eilès polinomus ịlinkių interpoliacinèms funkcijoms, palyginti su posūkių aproksimacija.

Ankstesniame darbe atliktuose skaitiniuose testuose taikant mišry susietos interpoliacijos elementą Q4BL, pastebèta jog šis elementas turi nulines energetines formas. Dèl šios priežasties tam tikrais atvejais, modeliuojant elementu Q4BL, sprendinys gali būti nestabilusis. Nauja šio 
elemento versija Q4BLa testuota statikos uždaviniams ir šie rezultatai pateikti darbe [7]. Šiame darbe pateikiama šios naujos elemento versijos formuluotè dinaminiams uždaviniams bei testavimo rezultatai laisvųjų svyravimų uždavinių atveju, modeliuojant tiek plonas, tiek storas plokšteles.

Antrajame skyriuje pateikiama mišri baigtiniu elementu formuluote, skirta laisvujų svyravimu analizei. Ši plokštelès baigtinio elemento formuluotè paremta Reissner-Mindlin plokšteliu teorijos prielaidomis. Џlinkiu aproksimacijai yra taikomos interpoliacinès funkcijos, susiejančios jlinkius su posūkiais. Posūkiai ir šlyties jègos aproksimuojamos savarankiškomis interpoliacinemis funkcijomis. Taikant standartinę Galiorkino procedūrą, sudarytos pagrindinès baigtiniu elementu matricu išraiškos. Kadangi šlyties jègos aproksimuotos trükiosiomis funkcijomis, jas galima nesunkiai eliminuoti elemento lygmenyje ir gauti tiktai "poslinkių" formuluotę. Tuo pat metu sumažinamas ieškomujju parametrų skaičius.

Trečiajame skyriuje parodyti pagrindiniai elemento Q4BLa ieškomieji parametrai (1 pav.). Pateiktos pagrindinès interpoliaciniu funkciju išraiškos. Išdèstyta susietụ interpoliaciniu funkciju sudarymo metodologija. Šios susietos interpoliacinès funkcijos turi hierarchinę struktūrą. Mišraus elemento stabilumo kriterijai rodo, jog nagrinèjamas elementas neturès nulinių energetinių formų. Atlikus kondensaciją elemento lygmenyje, vienas elementas Q4BLa turi 20 nežinomujų parametrų. Siekiant padidinti skaičiavimo efektyvumą, taikomas skirtingos tikslumo klasès skaitinis integravimas, nustatant atskiry elemento matricy narių reikšmes.

Ketvirtajame skyriuje aptariami atliktu skaitinių eksperimenty rezultatai. Pradžioje pateikiami rezultatai, gauti modeliuojant skirtingo storio laisvai paremtas plokšteles. Gautas geras visu tyrinètu gautu tikriniu reikšmiu taikant Q4BLa elementą atitikimas analitiniams sprendiniams tiek plonų, tiek storų plokšteliu atvejais. Elemento jautrumas geometriniams iškreipiams tyrinètas istrižų plokšteliu pavyzdžiuose. Gauti rezultatai rodo, jog galima patikimai modeliuoti plokšteles, taikant elementus Q4BLa, neturinčius taisyklingos stačiakampio formos.

Romualdas BAUŠYS. Doctor, Senior Researcher, Associate Professor. Vilnius Gediminas Technical University, Laboratory of Numerical Modelling. Sauletekio al. 11, 2040 Vilnius, Lithuania.

PhD (1989). Common research with scientists from Chalmers University of Technology (Göteborg, Sweden). Research interests: error estimation and adaptive finite element strategies in statics and dynamics, optimisation and analysis procedures for non-linear problems. 